\title{
DEGREE OF LAND DEGRADATION IN THE UPPER MAHAWELI CATCHMENT AREA (AN INDICATIVE MAP GENERATED USING GEOGRAPHIC INFORMATION SYSTEMS)
}

\author{
C M M M K Chandrasekera, H Manthrithilake \\ Environment \& Forest Conservation Division \\ Mahaweli Authority, Dam Site, Polgolla
}

The Upper Mahaweli Catchment (UMC) is located in the central hills of Sri Lanka. Total surface area is $3110.81 \mathrm{Km}^{2}$ with the sub-catchments of Kotmale, Victoria, Randenigala and Rantembe. During the past few decades, land degradation has increased due to changes in plantation agriculture, population growth and inappropriate land management practices on steep slopes in the UMC area.

This study was carried out to identify land quality in three basic levels: degraded lands, degrading lands and good lands in the UMC area. From the agricultural perspective, the effect of land degradation could be linked to the natural fertility levels of the land or crop yield characteristics. As such data was not available, present land cover and slope were used as indicators of land degradation. Assumption is that, land cover could be taken as a cumulative result of fertility levels, natural quality of soils $\&$ climate and anthropological impacts. Accuracy was checked by field investigation.

The results of this study can be useful for watershed management, agricultural resources management and planning, to develop guidelines and policies.

Proceedings of the Third Annual Forestry Symposium 1997, of the Department of Forestry and Environmental Science, University of Sri Jayewardenepura, Sri Lanka 